\title{
Selection of Superior Ber (Ziziphus jujuba L.) Genotypes in Çivril Region
}

\author{
Fevzi M. ECEVIT ${ }^{1}$ \\ Bekir ŞAN ${ }^{1}$ \\ Tuba DILMAÇ ÜNAL ${ }^{1}$ \\ Filiz HALLAÇ TÜRK ${ }^{1}$ \\ $\begin{array}{lll}\text { Adnan N. YILDIRIM } & & \text { Mehmet POLAT } \\ & & \text { Fatma YILDIRIM }^{1}\end{array}$
}

Geliş Tarihi: 25.102007

\begin{abstract}
The objective of this research performed between 1999 and 2001 was the selection of promising ber genotypes in ber population in Çivril, Denizli region and then the preservation as genetic resources. For this purpose, 52 genotypes were selected and evaluated for their superior fruit characteristics and productivity. Promising genotypes were selected using the 'Weighted-Ranged' method. 7 genotypes were selected based on fruit volume, yield, flesh/stone ratio, total soluble solids and vitamin C. The yield of selected genotypes changed between 6.34 and $17.28 \mathrm{~g}$ per annual shoot. The fruit characteristics for the selected genotypes were ranged from 4.52 to $6.12 \mathrm{~g}$ for fruit weights, $0.34-0.41 \mathrm{~g}$ for stone weights, $11.02-16.15$ for flesh/stone ratio, $28.10-30.03 \%$ for total soluble solids, $31.43-33.63 \%$ for total solid, $225.3-366.0 \mathrm{mg} 100 \mathrm{~g}^{-1}$ for vitamin C, $2.17-3.0 \%$ for ash, $0.47-0.68 \%$ for total nitrogen and $2.91-4.24 \%$ for total protein.
\end{abstract}

Key Words: Ber, Ziziphus vulgaris L., selection

\section{Çivril Bölgesinde Yetişen Üstün Özellikli Ünnap (Ziziphus jujuba L.) Genotiplerinin Seleksiyonu}

Öz: 1999-2001 yılları arasında yapılan bu çalışmada Denizli'nin Çivril ilçesinde doğal olarak yetişmekte olan üstün özellikli ünnap tiplerinin seleksiyonu amaçlanmıştır. Yapılan ön seleksiyon sonucunda değerlendirmeye alınan 52 ünnap tipi tartılı derecelendirmeye tabi tutulmuş ve üstün özellikli bulunan 7 ünnap tipi seçilmiştir. Seçilen tiplerin verimleri 6.34-17.28 g/yıllık sürgün arasında değişmiştir. Seçilen tiplerin meyve ağırı̆̆ı, çekirdek ağırıı̆ı, meyve eti çekirdek oranı, suda çözünebilir toplam kuru madde miktarı, toplam kuru madde miktarı, vitamin C, kül, azot ve protein içerikleri sırasıyla 4.52-6.12 g, 0.34-0.41g, 11.02-16.15, \%28.10 30.03 \% \%31.43-33.63, 225.3-366.0 mg/100g, \%2.17-3.0, \%0.47-0.68 and \%2.91-4.24 olarak belirlenmiştir.

Anahtar Kelimeler: Ünnap, Ziziphus vulgaris L., seleksiyon

\section{Introduction}

Ber (Ziziphus spp), belonged to the family Rhamnaceae that consists of 45 genera and 550 species, is widely distributed in tropical and subtropical climates in the world (Mukhtar et al. 2004). These trees grow up to $12 \mathrm{~m}$ in height. Ber is a hardy tree of arid region which can be grown succesfully in saline soil under hot, arid environment ( Meena et al. 2003). Its fruits are palatable and delicious with a good amount of vitamin A, C and B complexes and minerals (Pareek, 2002). On the other hand, alkaloids, flavonoids, sterols, tannins, saponin, and fatty acids have been isolated and chemically idendified from the different species of the genus Ziziphus (Croueour et al. 2002; Abdel-Zaher et al. 2005; Bhargava et al. 2005; Zhao et al. 2006) Besides, ber has significant levels of antioxidant activity, reducing power, scavenging effect on free radicals ( $\mathrm{Li}$ et al. 2005). Because of these properties, Ziziphus species are used in folk medicine for the treatment of some diseases in the world (Belford, 1994; Crouẻour et al. 2002; Abdel-Zaher et al. 2005; Li et al. 2005). Its barks is used to heal ulcer, wounds, scabies, throat problems and burning sensation of the body. Its fruit purify and enrich blood, treat chronic bronchitis, fever and enlargement of the liver. Ber seeds are used to treat dry cough and skin eruptions. The juice of ber root is used as a purgative and externally in gout and rheumatism (Mukhtar et al. 2004). Its leaves are used for the treatment of diabetes mellitus (Abdel-Zaher et al. 2005). 
Ber demonstrates a rich genetic diversity mostly resulting from natural cross pollination and self incompatibility (Bhargava et al. 2005). Turkey has a genetic variation for this species in some of its regions due to croos-pollinations. There is a genetic variation in native ber population in forms of fruit volume, yield and other characteristics. Standard cultivar production is a very significant process in the fruitculture. There has not been any a study regarding the selection of ber in Turkey.

Thus, it is necessary to select desired genotypes for superior fruit characteristics and to develop standart cultivars from a wide variety of natural population.

The objective of this study was to select fruitful and high quality ber genotypes grown naturally in Civril, Denizli, Turkey.

\section{Material and Methods}

The study was performed on naturally grown ber population in Civril, Denizli, Turkey. Fifty two genotypes from this ber population were selected as a research material based on their high yield and attractive appearance of fruits in the first year, 1999. The trees were approximately $15-50$ years old. The following characteristics were evaluated for the harvested fruit: Morphological characteristics: Fruit weight $(\mathrm{g})$, fruit volume $(\mathrm{ml})$, stone weight $(\mathrm{g})$, fruit length $(\mathrm{mm})$, fruit width $(\mathrm{mm})$ and fruit flesh/stone ratio. Chemical analyses: total soluble solids (\%), total solids (\%), vitamin C (mg $\left.100 \mathrm{~g}^{-1}\right)$, ash (\%), total nitrogen (\%) and protein (\%) contents.

In order to chose the promising genotypes, the selection criteria used at the end of 3 years study were yield, fruit volume, flesh/stone ratio, total soluble solids and vitamin $\mathrm{C}$. Then based on the 'Weighted-Ranged' (WR) results, 7 genotypes with a minimum score of 670 were selected.

Yield of genotypes were evaluated according to total fruit weight per annual shoot. Average fruit volume, fruit weight, stone weight, fruit width and fruit length were determined on 100 randomly-choosen fruit, and flesh/stone ratio was calculated using the formula the weight of fruit with stone/stone weight.

Total soluble solids of the fruit were determined by a hand refractometer. Vitamin $\mathrm{C}$ content of fruit was determined as described (Anonymous, 1983). Total nitrogen and total protein contents of fruit were determined according to Kacar (1984).
Table 1. Characteristics, relative scores, classes and scores of the characteristics for 'Weighted-Ranged' method of ber genotypes

\begin{tabular}{|c|c|c|c|}
\hline $\begin{array}{l}\text { Characteristic } \\
\mathrm{s}\end{array}$ & $\begin{array}{l}\text { Relative } \\
\text { Scores }\end{array}$ & \multicolumn{2}{|c|}{$\begin{array}{c}\text { Classes and Scores of } \\
\text { the Charasteristics }\end{array}$} \\
\hline & & $\begin{array}{l}\text { Average fruit } \\
\text { Volume (ml) }\end{array}$ & \\
\hline \multirow[t]{4}{*}{ Fruit Volume } & 30 & $3.17-4.09$ & 1 \\
\hline & & $4.10-5.01$ & 4 \\
\hline & & $5.02-5.93$ & 7 \\
\hline & & $5.94-6.87$ & 10 \\
\hline \multirow[t]{5}{*}{ Yield } & 30 & $\begin{array}{l}\text { Total fruit weight } \\
\text { per annual shoot }(\mathrm{g})\end{array}$ & \\
\hline & & $3.07-6.67$ & 1 \\
\hline & & $6.68-10.27$ & 4 \\
\hline & & $10.28-13.87$ & 7 \\
\hline & & $13.88-17.47$ & 10 \\
\hline \multirow[t]{5}{*}{$\begin{array}{l}\text { Flesh/Stone } \\
\text { Ratio }\end{array}$} & 20 & $\begin{array}{l}\text { Fruit weight with } \\
\text { Stone/Stone weight }\end{array}$ & \\
\hline & & 8.94-10.85 & 1 \\
\hline & & $10.86-12.76$ & 4 \\
\hline & & $12.77-14.68$ & 7 \\
\hline & & $14.69-16.60$ & 10 \\
\hline \multirow[t]{5}{*}{$\begin{array}{l}\text { Total Soluble } \\
\text { Solids }\end{array}$} & 12 & $\begin{array}{l}\text { Refractometric } \\
\text { Value (\%) }\end{array}$ & \\
\hline & & $25.36-27.12$ & 1 \\
\hline & & $27.13-28.89$ & 4 \\
\hline & & $28.90-30.65$ & 7 \\
\hline & & $30.66-32.40$ & 10 \\
\hline \multirow[t]{5}{*}{ Vitamin C } & 8 & 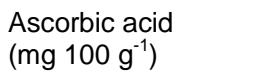 & \\
\hline & & $212-250$ & 1 \\
\hline & & $251-289$ & 4 \\
\hline & & $290-327$ & 7 \\
\hline & & $328-366$ & 10 \\
\hline
\end{tabular}

Evaluation of the total 'Weighted-Ranged' Scores: The modified 'Weighted-Ranged' (WR) method was used to determine the promising ber genotypes (Şen, 1986; Güleryüz et al. 1998; Serdar and Soylu, 1999; Demir and Beyhan, 2000). The characteristics evaluated with the WR method and their relative scores were shown in Table 1 . The relative scores were multiplied by the each characteristics score and summed to obtain WR scores for the each ber type.

\section{Results}

Fruit characteristics of 52 ber genotypes were evaluated (Tables 2). There were differences among the genotypes in terms of morphological, physical and chemical characteristics. Average data of the 3 years 
ECEVIT, F.M., B. ŞAN, T. DILMAÇ ÜNAL, F. HALLAÇ TÜRK, A. N. YILDIRIM, M. POLAT ve F. YILDIRIM, "Selection of superior ber (Ziziphus jujuba L.) genotypes in Çivril region"

Table 2. Some characteristics and 'Weighted-Ranged' scores of the genotypes studied

\begin{tabular}{|c|c|c|c|c|c|c|}
\hline Types No & $\begin{array}{c}\text { Yield per } \\
\text { annual shoot }(\mathrm{g})\end{array}$ & $\begin{array}{c}\text { Fruit Volume } \\
(\mathrm{ml})\end{array}$ & $\begin{array}{c}\text { Flesh/Stone } \\
\text { ratio }\end{array}$ & $\begin{array}{l}\text { TSS } \\
(\%)\end{array}$ & $\begin{array}{l}\text { Vitamin C (mg } \\
\left.100 \mathrm{~g}^{-1}\right)\end{array}$ & WR Score \\
\hline 20-Ç-1 & 3.07 & 6.55 & 13.02 & 25.37 & 251.7 & 514 \\
\hline 20-Ç-2 & 4.57 & 6.54 & 14.81 & 30.07 & 236.7 & 622 \\
\hline 20-Ç-3 & 3.24 & 6.79 & 12.69 & 31.03 & 327.7 & 646 \\
\hline 20-Ç-4 & 7.39 & 6.87 & 15.02 & 30.03 & 225.3 & 712 \\
\hline 20-Ç-5 & 5.45 & 6.54 & 14.62 & 27.80 & 278.0 & 610 \\
\hline 20-Ç-6 & 4.34 & 6.29 & 11.37 & 29.67 & 317.3 & 550 \\
\hline 20-Ç-7 & 5.21 & 6.62 & 13.28 & 28.40 & 278.3 & 550 \\
\hline 20-Ç-8 & 5.92 & 6.75 & 14.48 & 28.17 & 255.7 & 610 \\
\hline 20-Ç-9 & 4.09 & 6.47 & 15.14 & 28.70 & 218.0 & 586 \\
\hline 20-Ç-10 & 6.34 & 6.95 & 15.69 & 29.93 & 309.3 & 670 \\
\hline 20-Ç-11 & 6.56 & 5.94 & 13.17 & 27.27 & 262.0 & 550 \\
\hline 20-Ç-12 & 7.06 & 6.27 & 13.97 & 29.07 & 257.3 & 676 \\
\hline 20-Ç-13 & 8.43 & 6.00 & 13.02 & 26.70 & 250.7 & 580 \\
\hline 20-Ç-14 & 5.69 & 6.74 & 16.60 & 27.67 & 212.0 & 586 \\
\hline 20-Ç-15 & 5.87 & 6.70 & 14.32 & 27.50 & 251.3 & 610 \\
\hline 20-Ç-16 & 7.13 & 6.74 & 14.28 & 28.60 & 291.3 & 724 \\
\hline 20-Ç-17 & 7.29 & 5.97 & 13.44 & 28.33 & 265.0 & 640 \\
\hline 20-Ç-18 & 5.68 & 6.17 & 12.46 & 28.87 & 313.3 & 574 \\
\hline 20-Ç-19 & 10.97 & 3.67 & 10.90 & 29.80 & 274.0 & 436 \\
\hline 20-Ç-20 & 7.47 & 5.90 & 12.83 & 27.53 & 290.0 & 574 \\
\hline $20-C ̧-21$ & 7.61 & 3.24 & 12.29 & 30.33 & 284.0 & 406 \\
\hline 20-Ç-22 & 9.33 & 6.52 & 16.15 & 29.80 & 271.3 & 676 \\
\hline 20-Ç-23 & 8.26 & 4.95 & 11.67 & 29.93 & 330.0 & 484 \\
\hline 20-Ç-24 & 7.03 & 5.54 & 11.59 & 27.27 & 327.3 & 514 \\
\hline 20-Ç-25 & 7.73 & 4.19 & 11.60 & 29.47 & 284.7 & 436 \\
\hline 20-Ç-26 & 6.13 & 4.59 & 11.27 & 28.60 & 282.0 & 310 \\
\hline $20-C ̧-27$ & 10.25 & 5.19 & 12.36 & 25.80 & 268.0 & 514 \\
\hline 20-Ç-28 & 10.11 & 3.74 & 13.49 & 29.03 & 330.0 & 454 \\
\hline 20-Ç-29 & 5.34 & 3.60 & 13.78 & 28.30 & 264.7 & 280 \\
\hline 20-Ç-30 & 8.55 & 3.26 & 15.04 & 28.03 & 254.0 & 430 \\
\hline 20-Ç-31 & 8.20 & 4.70 & 9.69 & 30.57 & 250.7 & 436 \\
\hline 20-Ç-32 & 9.45 & 5.59 & 12.15 & 26.70 & 213.3 & 490 \\
\hline 20-Ç-33 & 7.64 & 3.90 & 12.42 & 26.53 & 245.3 & 310 \\
\hline 20-Ç-34 & 4.16 & 3.65 & 10.77 & 30.78 & 275.3 & 292 \\
\hline 20-Ç-35 & 3.08 & 3.17 & 9.91 & 30.50 & 221.0 & 232 \\
\hline 20-Ç-36 & 8.60 & 5.77 & 11.48 & 29.40 & 248.0 & 502 \\
\hline 20-Ç-37 & 4.09 & 3.79 & 12.48 & 30.17 & 234.7 & 292 \\
\hline 20-Ç-38 & 5.17 & 4.02 & 10.93 & 29.53 & 250.0 & 232 \\
\hline 20-Ç-39 & 3.21 & 4.00 & 11.97 & 30.70 & 228.0 & 328 \\
\hline 20-Ç-40 & 5.55 & 5.36 & 13.43 & 30.40 & 285.3 & 496 \\
\hline 20-Ç-41 & 11.54 & 5.37 & 12.48 & 29.93 & 246.0 & 652 \\
\hline 20-Ç-42 & 7.83 & 4.58 & 8.94 & 29.07 & 244.0 & 352 \\
\hline 20-Ç-43 & 8.44 & 5.27 & 12.47 & 30.60 & 242.7 & 562 \\
\hline 20-Ç-44 & 11.79 & 3.46 & 11.50 & 29.07 & 257.3 & 466 \\
\hline 20-Ç-45 & 17.47 & 3.91 & 11.93 & 30.47 & 234.7 & 502 \\
\hline 20-Ç-46 & 9.04 & 4.40 & 12.41 & 29.40 & 235.3 & 472 \\
\hline 20-Ç-47 & 6.31 & 5.09 & 9.29 & 28.63 & 234.7 & 316 \\
\hline 20-Ç-48 & 11.73 & 3.51 & 10.17 & 32.40 & 309.3 & 496 \\
\hline $20-\mathrm{s}^{5}-49$ & 11.99 & 4.78 & 11.09 & 30.40 & 246.7 & 502 \\
\hline 20-Ç-50 & 10.38 & 5.38 & 9.84 & 29.53 & 245.3 & 592 \\
\hline 20-Ç-51 & 17.28 & 5.37 & 11.02 & 29.44 & 366.0 & 694 \\
\hline 20-Ç-52 & 15.51 & 5.89 & 12.41 & 28.10 & 364.0 & 778 \\
\hline Minimum & 3.07 & 3.17 & 8.94 & 25.36 & 212.0 & 232 \\
\hline Maximum & 17.47 & 6.95 & 16.60 & 32.40 & 366.0 & 778 \\
\hline Average & 7.70 & 5.23 & 12.42 & 29.01 & 268,05 & 509,96 \\
\hline
\end{tabular}

were used for the evaluation of the 52 genotypes. The characteristics evaluated with WR method for 52 ber genotypes were presented in Table 2. The yield of the 52 genotypes ranged from 3.07 to $17.47 \mathrm{~g}$ per annual shoot. Fruit volumes of these genotypes were between 3.17 and $6.95 \mathrm{ml}$ while the flesh/stone ratio ranged from 8.94 to 16.60 . The contents of TSS and vitamin C of the 52 genotypes were between $25.37-32.40 \%$ and 221.0-366.0 mg $100 \mathrm{~g}^{-1}$ flesh fruit, respectively. After determination of the fruit characteristics, their scores for each ber genotypes were evaluated and given in Table 2. While the highest WR score was recorded for 20-C-52 genotype (778), the lowest WR score was for 20-Ç-35 and 20-Ç-38 genotypes (232). 
As a result, seven genotypes with 670 or higher WR score were selected based on the desired characteristics (Table 3 ). Of the selected genotypes, while $20-C ̧-51$ had highest yield (17.28 g per annual shoot), highest TS (33.63\%) and highest vitamin C $\left(366.0 \mathrm{mg} 100 \mathrm{~g}^{-1}\right), 20-C ̧-10$ had largest fruit $(6.12 \mathrm{~g}$ or $6.95 \mathrm{ml})$, highest fruit width $(23.65 \mathrm{~mm})$, fruit length $(25.23 \mathrm{~mm})$, total $\mathrm{N}(0.68 \%)$ and protein $(4.24 \%)$. 20 Ç-22 had smallest stone weight $(0.34 \mathrm{~g})$ and highest flesh/stone ratio (16.15).

\section{Discussion}

Yield, fruit volume and flesh/stone ratio are some of the principal objectives for breeding. Yields of the selected genotypes ranged from 6.34 to $17.28 \mathrm{~g}$ per annual shoot (about 50-80 kg per tree). Prasad (2005) reported that the greatest mean fruit yields were between 50.51 and $54.45 \mathrm{~kg}$ per tree. These results are in agreement with our results. However Kundi et al. (1989a) and Kundu et al. (1995) reported that the highest yield was $111.8 \mathrm{~kg}$ per tree and $88.33 \mathrm{~kg}$ per tree, respectively. This might result from different environmental conditions and genotypes.

Average fruit volumes of selected genotypes ranged between $4.52 \mathrm{~g}$ and $6.12 \mathrm{~g}$ or $5.37 \mathrm{ml}$ and $6.95 \mathrm{ml}$ based on three years evaluation. Sivakov et al. (1988) reported that fruit weight was between 5.72 and $10.45 \mathrm{~g}$. These results agree with our result. However the average fruit weight reported by some researches was between $10.0 \mathrm{~g}$ and $29.34 \mathrm{~g}$ (Kundi et al. 1989b; Gao et al. 2003; Liu et al. 2004; Prasad, 2005; jiang et al. 2006). The ber cultivars with larger volumes may possibly be triploid. On the other hand, it was shown that ber cultivars with smaller fruit had higher ascorbic acid, total sugar and total soluble solids than the ones with larger fruit (Sivakov et al. 1988; Kundi et al. 1989b; Gao et al. 2003; Chen et al. 2006 ). Besides, the cultivars with smaller fruit are more suitable for drying (Gao et al. 2003). For this raison, selected genotypes are suitable for drying and as a breeding material.

Stone weights of selected genotypes were between 0.34 and $0.41 \mathrm{~g}$. The average stone weight was determined between 0.28 and $0.65 \mathrm{~g}$ in 6 ber varieties (Sivakov et al. 1988) and between 0.6 and 1.9 $\mathrm{g}$ in 9 cultivars (Ghosh and Mathew, 2002). As seen here, the stone weights of the selected genotypes are smaller than in many ber cultivars.

Average flesh/stone ratios were between 11.02 and 16.15 for selected genotypes. Kundi et al. (1989b) investigated the fruit characteristics of 7 ber cultivars and reported that the highest pulp/seed ratio was 16.22. The present results are in agreement with the finding of Kundi et al. (1989b).

Total soluble solids and total solids of selected genotypes were 28.10-30.03 and 31.43-33.63, respectively. Pan et al. (2003) reported that the content of total solids and total soluble solids of ber variety 'Jingzao' were $21.7 \%$ and $25.4 \%$, respectively. Some researches reported that total soluble solids content of ber cultivars changed between $15 \%$ and $45 \%$ (Ma et al. 2000; Ghosh and Mathew, 2002; Gao et al. 2003; Chen et al. 2006; Jiang et al. 2006). This large differentiation might be due to genotypic differences.

In the present study, vitamin $C$ content of selected genotypes changed between 225.3 and 366.0 $\mathrm{mg} 100 \mathrm{~g}^{-1}$ pulp. Similar results were obtained for vitamin $\mathrm{C}$ content. The highest vitamin $\mathrm{C}$ content was determined to be $101.47 \mathrm{mg} 100 \mathrm{~g}^{-1}$ pulp for 'Haq Nawaz' cultivar (Kundi et al. 1989b) and $235.5 \mathrm{mg} 100$ $\mathrm{g}^{-1}$ pulp for 'Ilayachi' cultivar (Ghosh and Mathew, 2002). Sivakov et al. (1988) reported that vitamin C contents of 6 ber cultivars changed between 180.11

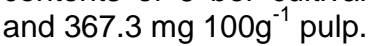

Table 3. Some characteristics of the promising ber genotypes

\begin{tabular}{|c|c|c|c|c|c|c|c|}
\hline \multirow[b]{2}{*}{ Properties } & \multicolumn{7}{|c|}{ Promising ber genotypes } \\
\hline & 20-Ç-4 & 20-Ç-10 & 20-Ç-12 & 20-Ç-16 & 20-Ç-22 & 20-Ç-51 & 20-Ç-52 \\
\hline Yield per annual shoot (g) & 7.39 & 6.34 & 7.06 & 7.13 & 9.33 & 17.28 & 15.51 \\
\hline Fruit Volume (ml) & 6.87 & 6.95 & 6.27 & 6.74 & 6.52 & 5.37 & 5.89 \\
\hline Fruit weight (g) & 6.01 & 6.12 & 5.31 & 5.57 & 5.49 & 4.52 & 4.84 \\
\hline Stone weight $(\mathrm{g})$ & 0.40 & 0.39 & 0.38 & 0.39 & 0.34 & 0.41 & 0.39 \\
\hline Flesh/Stone ratio & 15.02 & 15.69 & 13.97 & 14.28 & 16.15 & 11.02 & 12.41 \\
\hline Fruit width (mm) & 22.16 & 23.65 & 20.94 & 21.57 & 21.55 & 17.27 & 19.56 \\
\hline Fruit length (mm) & 23.76 & 25.23 & 22.24 & 23.38 & 22.69 & 16.86 & 21.58 \\
\hline TSS (\%) & 30.03 & 29.93 & 29.07 & 28.60 & 29.80 & 29.44 & 28.10 \\
\hline TS (\%) & 32.90 & 32.63 & 31.53 & 31.70 & 33.00 & 33.63 & 31.43 \\
\hline Vitamin C (mg $\left.100 \mathrm{~g}^{-1}\right)$ & 225.3 & 309.3 & 257.3 & 291.3 & 271.3 & 366.0 & 364.0 \\
\hline Ash (\%) & 3.00 & 2.17 & 2.38 & 2.31 & 2.20 & 2.70 & 2.75 \\
\hline Total N (\%) & 0.61 & 0.68 & 0.53 & 0.56 & 0.47 & 0.59 & 0.60 \\
\hline Protein (\%) & 3.83 & 4.24 & 3.28 & 3.49 & 2.91 & 3.71 & 3.90 \\
\hline
\end{tabular}


Ash content of selected ber genotypes changed between 2.17 and $3.0 \%$. In contrast to our results, Montiel-Herrera et al. (2005) reported that ash content of ber was $3.4 \%$.

While total $\mathrm{N}$ contents of selected genotypes were between 0.47 and $0.68 \%$, protein contents ranged from $2.91 \%$ to $4.24 \%$. Kundi et al. (1989b) reported that the protein content of 7 ber cultivars were between $1.24 \%$ and $2.96 \%$. The protein contents of our selected genotypes are higher than those in literature cited.

We selected the number of $20-C ̧-4,20-C ̧-10,20$ Ç-12, 20-Ç-16, 20-Ç-22, 20-Ç-51 and 20-Ç-52 genotypes as superior among the evaluated ber genotypes. These genotypes will be propagated and a replicated trial will be established and yield and fruit characteristics will be evaluated when trees reach maturity.

\section{Acknowledgment}

The Scientific and Technological Research Council of Turkey financially supported this research (Project No: TOGTAG-TARP-1988).

\section{References}

Abdel-Zaher, A. O., S. Y. Salim, M. H. Assaf and R. H. AbdelHady. 2005. Antidiabetic activity and toxicity of Zizyphus spina-christi leaves. Journal of Ethnopharmacology, 101 (1-3): 129-138.

Anonymous, 1983. Gıda maddeleri muayene ve analiz yöntemleri kitabı. T.C. TOKB Gıda işı. Genel müdürlüğü, Yayın No: 65.

Belford, R. 1994. Chinese herbal medicine treatment of chronic hepatitis. Australian Journal of Medical Herbalism, 6(4): 94-98

Bhargava, R., A. K. Shukla, N. Chauhan, B. B. Vashishtha and D. G. Dhardar. 2005. Environmental and Experimental Botany, 53(2): 135-138.

Chen, Y. Q., X. H. Zhong and L. F. Gan. 2006. The performance of 'Liuxiangzao' jujube cultivar and its cultural techniques. South China Fruits, No:1, 49-50

Croueour, G. L., P. Thepenier, B. Richard, C. Petermann, K. Ghedira and M. Zeches-Hanrot. 2002. Lotusine G: a new cyclopeptide alkaloid from Zizyphus lotus. Fitoterapia, 73(1): 63-68

Demir, T. and N. Beyhan, 2000. Research on the Selection of Hazelnuts Grown in Samsun. Tr. J. of Agriculture and Forestry, 24: 173-183.
Gao, L., G. F. Zhou and G. N. Shen. 2003. New jujube varieties and their cultural techniques. China Fruits No:2, $38-40$

Ghosh, S. N. and B. Mathew. 2002. Performance of nine ber (Ziziphus mauritiana Lamk) cultivars on topworking in the semi-arid region of West Bengal. Journal of Applied Horticulture, 4(1): 49-51

Güleryüz, M., İ. Bolat and L. Pırlak. 1998. Selection of Table Cornelian Cherry (Cornus mas L.) Types in Çoruh Valley. Tr. J. of Agriculture and Forestry, 22: 357-364.

Jiang, X. W., J. Q. Cao, J. X. Zeng and F. P. Huang. 2006. Jujube cultivars trials and study on their adaptability. South China Fruits, No:1, 51-52.

Kacar, B. 1984. Bitki Besleme ve Uygulama Kılavuzu, Ankara, s: 39-46.

Kundi, A. H. K., F. K. Wazir, G. Abdul and Z. D. K. Wazir 1989a. Morphological characteristics, yield and yield components of different cultivars of ber (Zizyphus jujuba Mill). Sarhad Journal of Agriculture 5(1) : 53-57.

Kundi, A. H. K., F. K. Wazir, G. Abdul and Z.D.K. Wazir, 1989b. Physico-chemical characteristics and organoleptic evaluation of different ber (Zizyphus jujuba Mill.) cultivars. Sarhad Journal of Agriculture, 5(2): 149155

Kundu, S. S., O. P. Pareek and A. K. Gupta. 1995. Effect of time and severity of pruning on physico-chemical characteristics and yield of ber (Zizyphus mauritiana Lamk.) cv. Umran. Haryana Journal of Horticultural Science 24(1): 23-30

Li, J.W., S. D. Ding and X. L. Ding. 2005. Comparison of antioxidant capacities of extracts from five cultivars of Chinese jujube. Process Biochemistry, 40 (11): 36073613.

Liu, J., H. H. Zhao, F. Li, X. H. Mei, M. Niu and S.S. He. 2004. Cultural techniques for early high production of jujube cultivar Dongzao. China Fruits No:6, 34-35

Ma, Y. K., S.Y. Wang, B. G. An, J. J. Sun and F. J. Yao. 2000. 'Juzhou Gongzao', a promising late jujube variety. China Fruits No: 1, 22, 38

Meena, S. K., N. K. Gupta, S. Gupta, S. K. Khandelwal and E. V. D. Sastry. 2003. Effect of sodium chloride on the growth and gas exchange of young Ziziphus seedling rootstocks. Journal of Horticultural Science and Biotechnology, 78(4): 454-457.

Montiel-Herrera, M., S. Campista-Leon, I. L. CamachoHernandez, A. Rios-Morgan and F. Delgado-Vargas. 2005. Physicochemical and nutritional characteristics of the fruit of Zizyphus sonorensis S. Wats (Rhamnaceae). International Journal of Food Sciences and Nutrition, 56(8): 587-596. 
Mukhtar, H. M., S. H. Ansari, M. Ali and T. Naved. 2004. New compounds from Zizyphus vulgaris. Pharmaceutical Biology, 42(7): 508-511.

Pan Q. H., J. Bai and B. Q. Wang. 2003. 'Jingzao 39', a new fresh eating variety of jujube. China Fruits, No:4, 3-4.

Pareek, O. P. 2002. Ber-Ziziphus mauritania. Available by International Centre for Underutilised Crops [Online]. Available:

http://www.civil.soton.ac.uk/icuc/cd icuc ber tamarind/c ontent/ber/ber_book_html via the INTERNET. Accesed 2004 Apr 6.

Prasad, R. N. 2005. Effect of N and P on growth, yield and quality of ber grown under rainfed conditions of Indian arid zone. Indian Journal of Horticulture, 62 (4): 404-406

Serdar, Ü. and A. Soylu. 1999. Samsun ilinde Kestane (C. sativa Mill) Seleksiyonu. Türkiye III. Ulusal Bahçe Bitkileri Kongresi, p. 736-740.

Sivakov, L., D. Georgiev, B. Ristevski and Z. Mitreski. 1988 Pomological and technological characteristics of Chinese jujube (Zyziphus jujuba) in Macedonia Jugoslovensko Vocarstvo, 22(4): 387-392
Sen, S. M. 1986. Kuzeydoğu Anadolu ve Doğu Karadeniz Bölgesi Cevizlerinin (Juglans regia L.) Seleksiyon Yoluyla Islahı Üzerinde Araştırmalar. Atatürk Üniv. Ziraat Fak. Bahçe Bitkileri Bölümü.

Zhao, J., S. P. Li, F. Q. Yang, P. Li and Y. T. Wang. 2006. Simultaneous determination of saponins and fatty acids in Ziziphus jujuba (Suanzaoren) by high performance liquid chromatography-evaporative light scattering detection and pressurized liquid extraction. Journal of Chromatography A, 1108(2):188-194.

Communication address:

Bekir ŞAN

Süleyman Demirel University, Faculty of Agriculture, Department of Horticulture-Isparta/Turkey

Phone: 02462114655

E-mail: bekirsan@ziraat.sdu.edu.tr 